RGSA - Revista de Gestão Social e Ambiental

Jan. - Abr. 2010, V.4, No.1, p. 228-241 ${ }^{1}$

www.gestaosocioambiental.net

\title{
ETHICS AND SUSTAINABLE DEVELOPMENT
}

\section{Daniel Arruda Coronel}

Doctorate student in Applied Economics at the Federal University of Viçosa (UFV), Economist from the University of Santa Maria (UFSM) and Doctorate Scholarship holder of the Conselho Nacional de Desenvolvimento Científico e Tecnológico (CNPq). E-mail: daniel.coronel@ufv.br

\section{José Maria Alves da Silva}

Associate Professor of UFV, Doctor of Economy at the University of Sao Paulo (USP). E-mail: jmasilva@ufv.br

\begin{abstract}
Alex Leonardi
Doctorate student in Agribusiness at the Federal University of Rio Grande do Sul ((UFRGS), Economist from the Federal University of Santa Maria (UFSM) and Doctorate Scholarship holder of the CAPESCoordenação de Aperfeiçoamento de Pessoal de Nível Superior (CAPES). E-mail: alex.leonardi@ibest.com.br
\end{abstract}

\begin{abstract}
The objective of this article is to bring hermeneutic considerations and philosophies concerning ethics, economy and environment, with a specific focus on the relationship between Kant's categorical imperative and the issue of sustainable development. The economic perspective of Georgescu-Roegen has been considered, for this purpose. Although economy, ethics and biology constitute distinct fields of specialization, this work seeks to show reasons for which this perspective could be seen as an intersection between the three disciplines. The article concludes with the message of Georgescu-Roegan, held in his saying "minimal bioeconomic program" in accordance with the fundamental precepts of the Kantian ethics, in respect to the issue of sustainability.
\end{abstract}

Keywords: Ethics; Sustainable Development; Kant; Georgescu-Roegen; Bioeconomy

\section{Resumo}

O objetivo deste artigo é tecer considerações hermenêuticas e filosóficas sobre ética, economia e meio ambiente, enfocando, mais especificamente, a relação entre o imperativo categórico formulado por Kant e a questão do desenvolvimento sustentável. Para isso, considerou-se como elemento de ligação a perspectiva econômica de Georgescu-Roegen. Embora a economia, a ética e a biologia constituam campos distintos de especialização, o trabalho procurou mostrar as razões pelas quais essa perspectiva pode ser vista como uma área de interseção entre estas três disciplinas. Conclui-se que as recomendações de Georgescu-Roegen, contidas no seu chamado "programa bioeconômico mínimo", estão de acordo com os preceitos fundamentais da ética kantiana, no que respeita à questão do desenvolvimento sustentável.

Palavras-chave: Ética; Desenvolvimento Sustentável; Kant; Georgescu-Roegen; Bioeconomia

\footnotetext{
${ }^{1}$ Recebido em 17.02.2010. Aprovado em 01.04.2010. Disponibilizado em 28.04.2010. Avaliado pelo sistema double blind review
} 


\section{INTRODUCTION}

Recently the issue of sustainable development has deserved great acknowledgement in the press with the recent publications of international reports and their alarming conclusions on climatic problems of the planet. Frequently the warnings of these studies are spread by the media in an alarmist manner, without taking into consideration certain questions that are at the heart of the problem.

In the 1970's, concerns about of sustainable development latently began through the publication, mostly by the Club of Rome ${ }^{2}$, of the work Growth Limit, which defined five inhibiting points of economic growth: population, agricultural production, natural resources, industrial production and contamination. Starting from there, discussions and debates grew over sustainable development, generalizing the concept from the Brundtland report (1987) and reaching its peak in the United Nations Conference on the Environment and Development in Rio de Janeiro, 1992, in which Agenda 21 was defined, or in other words, a set of assumptions that nations should adopt with sustainability in mind.

In the Brundtland report, sustainable development is defined as development "which attends to the necessities of the present without compromising the possibility of future generations to attend to their own necessities" (World Commission on Environment and Development, 1987). From this concept the discussion has evolved, almost always revolving around the search of a supposed balance between the economical, social and environmental dimensions.

Be it at the national (Gladwin et al., 1995; Banerjee, 2003; Greaker, 2003; Anton et al., 2004; Spangenberger, 2004) or at the business management level (Buysse; Verbeke, 2003; Russo, 2003; Bansal, 2005; Sharma; Henriques, 2005 and Barin-Cruz et al., 2006), sustainable development entered into the concern list of public and private managers. Moreover, it began to be understood and discussed in a increasingly diffused manner in society.

Considering individual ethics, beginning with the kantian categorical imperative, the behavior of each individual should be based on the following maximum: act in such a way that the maximum of your actions can become a universal law, or even more, act in a way so that the reason which took you for acting in such a way can be converted into universal law. Would it then be credible to consider sustainable development from the kantian categorical imperative? If yes, what would it imply?

This article is developed on such premises. From a transdisciplinary perspective, it aims to show the relationship and implications between sustainable development, the GeorgescuRoegen bioeconomy and the Kant categorical imperative. For all this, the text is divided into four sections, aside from this introduction. The second section defines and classifies the concept of ethics and its objective, as a philosophical discipline, aside from its relation with the other areas of learning and its evolution from ancient Greece up to present. The third section, from the conventional definitions, reviews the concept of sustainable development under GeorgescuRoegen views. The fourth section establishes a relation between the categorical imperative and bioeconomy. At last, some considerations and general conclusions are presented on the questions raised.

2 The Club of Rome appeared in 1968 formed by scientists of several nationalities, having since objective discusses the problems that were afflicting the humanity, as well as, from concrete policies, to aim solving these problems.

(C) RGSA - v.4, n.1, jan./abr. 2010

www.gestaosocioambiental.net 


\section{THE CONCEPT OF ETHICS}

It is possible to define ethics as the discipline that looks at human actions and its rules or principles or ideals in the sense of determining what the best individual or social actions are in relations between men, or in other words, ethics implies relations with other beings.

According to Vázquez (2006, p.23), "ethics is the theory or science of moral behavior of men in society. Or in other words, it is the science of the specific manner of human behavior." The objective of study and the research involving ethics focuses on human actions, or in other words, voluntary and conscious acts of humans that affect other individuals, other social groups and other people.

In traditional philosophy, according to Napoli (2000) and Vázquez (2006), ethics is classified into three types: Descriptive Ethics, Normative Ethics and Metaethics. The first is related with empirical questions, or in other words, with principles and values of a determined time or place, without worrying about establishing judgments on what is right or wrong, or in other words, without getting into the essence or physis of the problem. Normative Ethics is connected to abstract questions of human actions, which according to Vázquez (2006), the normative conception has as its assumptions making recommendations and formulating standards. Nevertheless these recommendations do not reach the theory of ethics, which tries to explain the mainstay of morality related to the actions of man. In Metaethics, according to Napoli (2000), the logical level of conceptualized affirmations and propositions, or in other words, the type of reflection that analyzes the moral discourse constituting a metalanguage of intentionally neutral or non-prescriptive characters is understood.

Ethics questions, despite being studied more by philosophers, cannot be usurped by philosophy, according to Mendonça (2003), since they involve transdiciplinary concepts like freedom, justice, sociability, sustainability, values and necessities, shared with different areas of knowledge.

Rights are intimately connected with ethics, since it also works towards justice and the common good and justice is the center of reflection and ethical problems. Ethics is gnosiologically interlaced with psychology, sociology and anthropology, keeping in mind that psychology makes the actions and attitudes of man possible to understand, in this way contributing to the explanation of human actions in the moral dimension. Anthropology and sociology are already connected with ethics, since they study the behavior of man as a social being, how he is placed in a society and what his relationship with other individuals is (Vazquez, 2006).

The relationship between ethics and applied social sciences was considered by Max Weber. In the work "Protestant Ethics and the Spirit of Capitalism" (Weber, 2006), capitalism is introduced as a social order backed by an ontologically disconnected doctrine of dogmas of medieval Catholicism and validated by favorable ethics to capitalist interests.

In Medicine, the concept of ethics is related to Bioethics, which according to Loreto (2003), should be understood as the necessary conditions for a responsible administration of human life, considering the moral responsibility of the scientists and investigators with human life.

The concept of ethics goes back to ancient Greece. However, throughout history, with the evolution of science and the systematization of knowledge, it suffered several transformations without losing, nevertheless, its essence.

(C) RGSA - v.4, n.1, jan./abr. 2010

www.gestaosocioambiental.net 
In ancient Greece, it is observed, on the basis of philosophical assumptions of the sophists $^{3}$, Socrates (2002), Plato (2004) and Aristotle (2004), three aspects of ethics: that of the sophists movement, with emphasis on the use of ethics and rhetoric to persuade and obtain results in the political life; that of Socrates (2002), with the emphasis on virtues and kindness, or in other words, while knowing good and virtues, man tries to act in such a way as to practice them, and the ethics of Plato (2004) and Aristotle (2004), connected with politics and the moral virtues of duties and civic rights.

In the Middle Ages, according to Spinelli (2002), the concept of ethics was connected with Christian philosophy, it means, assumptions and truths related to God, which man should follow while striving for salvation and divine contemplation. Christian ethics has a tendency to regulate the actions, attitudes and thoughts of people keeping in mind another world, placing God as an end, as Lord of all things and all people.

Modern ethics, in agreement with Vázquez (2006), has a new redimensioning; the christian vision of ethics with the focus on God disappears and a vision with an emphasis on man, the anthropocentric vision which makes man the center and basis of the universe, though he is conceived in abstract and gifted in a universal and inalterable nature. In modern ethics the philosophical-ethical assumptions of Kant (2003) and Weber (2006) are noted.

For Kant (2003), ethics consists not in taking people as a half or end. Kantian ethics is autonomous and formal in that it formulates for men a duty independent of his social and economical conditions since he is a free, active, productive and creative being.

The ideas of Kant are a logical result of his belief in the basic freedom of the individual, as affirmed in his Critique of Practical Reason (2003). This freedom cannot be confused as anarchism, but should be understood more like the freedom of auto-governmental, the freedom to consciously obey universal laws as a revealed by the reason.

The protestant ethics formulated by Weber was considered by the European capitalist bourgeoisie justifying the man actions of searching profit and wealth. The Weber's ideas were the theoretical point for the capitalist system reinforcement. Still on this perspective, according to Cherques (1997), p. while studying the protestant ethics, Weber explained the modern capitalism by analyzing the possibilities of its origin.

Contemporary ethics can be divided into two parts, the ethics of the XX century, which reproduces philosophical discussions of subjects like existentialism and social justice, and that of the XXI century that is concerned about the environment, sustainable development, social inequalities, political questions and the responsibility of man with the future of society

Existentialism has a new connotation from the philosophical assumptions of Sartre (1996), which conceives man as a free being by nature, having his actions been unconditional as social, economical, physical, cultural and psychological forces.

The relationship between ethics and social justice finds its theoretical bases in Rawls (2002), which conceives that the sense of justice shows in two forms: when just institutions that are applied to all are accepted, in such a way that the acceptance and loyalty guarantees that rivalries between the people will be treated equally; and when people are prepared to work on behalf of just institutions and to make changes when necessary. When the principal morality is achieved, moral development is complete, and this can take two forms: the first corresponds to the feeling of the just and justice; and the second to the love of humanity.

3 In agreement with Spinelli (1998), they can define the sophists like an intellectual movement of Ancient Greece, but that lost his extract while trying to make use of the knowledge and of the rhetoric for persuasion and getting privileges and wealth.

(C) RGSA - v.4, n.1, jan./abr. 2010

www.gestaosocioambiental.net 
According to Rawls (2002) the most fundamental assumptions of the justice sense is that each person must have freedom, as extensive as possible, in as much as is compatible with the freedom similar to that of the other individuals.

Morin (2005) discuss on ethic questions, bringing out the auto-ethics, focusing on questions not linked to the moral and politics epistemology, but to elements such as social, cultural, educational responsibility of man in the society where he lives, the capacity of man to reflect on the way he interacts with society through elements like honor, tolerance, responsibility, self criticism and self analysis.

A great example of the ethical and social preoccupation of man with society can be found in the letters of Albert Einstein and Sigmund Freud, from 1932, entitled Why War? In the correspondence between these two of the major characters in scientific history, the concern and anxiety of both for the future of international relations can be observed, more specifically with the capacity of the League of the Nations to promote peace and sustainable development in society. These questions are out of the context of their respective areas of work and inquiry. The ethical worries and discussions of the new millennium are centered on issues like equal opportunities, political rights, and mainly, questions related to the environment and the concept of sustainable development.

\section{SUSTAINABLE DEVELOPMENT}

With Aristotel, the economy appeared like a branch of ethics: the ethics of the relationship in the activities of material life sustenance (Nicomachean Ethics, 2004). So, in Aristotelian view, the link between ethics and sustainable development can't be broken, because the activities are not neutral with respect to natural environment. Nevertheless, Aristotel did not have in mind environmental questions. He sought to secure an ethics of justice, as his principle of the just trade shows, according to which the exchange of goods between two men must serve to improve the conditions of life of both and not constituting anything where one could benefit on another. Assimilated by Christian doctrine, the aristotelic principle of just exchange was incorporated into the political economy for centuries, until, with the advent of enlightenment, the economy began to be identified by the concepts of pleasure and self interest, changing more and more into what Aristotle himself had defined as "crematism". (Politics, 2004).

Environmental concerning are quite recent in human history. It comes about in a more spread form in the second half of the XX century. The studies of Carson (1962), GeorgescuRoegen (1971), and Schumacher (1983) constitute seminal references on this subject. In the book "Silent Spring", Rachel Carson reports the results of investigations on the effects of chemical synthetic agents in living organisms. This work constituted the first great alert of the sanitary dangers and environmental risks of pesticides. The proof of the endocrinous disruption provoked by DDT and ecological damages created a new government-political posture regarding the use of agrochemicals which culminated into the act of creation of the Enviromental Protecion Agency (EPA), by President John F. Kennedy.

The work of E. F. Schumacher constituted one of the first challenges to the "myth of economic progress" while attracting attention to the environmental impacts from large potential industries, highly intensive in energy consumption and pollution. His most aggressive message supported by energy statistics, was simply that the North American way of life could not be taken as a world reference, since it might not be supported for much longer. That saying strongly against the neoclassic theory of economic growth, which predicted the convergence of income 
between countries. As the Schumacher's work clearly pointed out, it is the problem with this theory is that it simply disregards the restrictions presented by the availability of non renewable natural resources like coal, oil and water.

But, the most general treatment, or even holistic, about the relationship between the economical development, ethics and environment is supplied by the romanian economist rooted in the USA, Nichollas Georgescu-Roegen (1906-1994), in series of fertile and innovatory works. This is a reason for which, instead of a multivaried and superficial review of several authors, it was opted to perform a more detailed examination here of the contributions of this important author on the subject in question ${ }^{4}$.

His work in this field consists of substantial criticism to the transplanted mechanistic paradigm, by the founders of the neoclassic school, of the newtonian physics for the economy, in which the economic system is represented as if it were a reproducible type, i.e. able to reproduce all the energy that it consumes. However, that applies only to the work and capital resources, which usually appear explicitly in the neoclassic function of production. The resultant product of the application of these resources can be used to support them in a constant or growing level to recompose the energy spent by the workers in the productive effort and put the capital stock back, in constant (stationary reproduction) or growing (enlarged reproduction) scale. But, in this process, the collection of natural resources, like land, water, forests and ores, necessarily suffers an entropic degradation. However, its habitual omission in the argument of the production function seems to presuppose that while capital is accumulated and the population grows, "everything remains constant".

This is the reason for which, like a dissident species of the neoclassic mainstream of which it was removed in the 1960's, Georgescu-Roegen proposed the analogy of entropic systems described by physical thermodynamics instead of the neoclassical model of mechanistic inspiration $^{5}$ for the economical system.

The idea that the economic process is not an analogous mechanism, but an entropic transformation, unidirectional, began to revolve in my mind, a long time ago, when I witnessed the oil wells of the fields dry up one by one and grew conscious of the struggle of the Romanian peasants against the deterioration of his soil worn away by continuous use and by the erosion of the rains. However, it was the new representation of a process that allowed to me to crystallize my reflections in describing, for the first time, the economic process as an entropic conversion of valuable natural resources (low entropy) into residues without value (high entropy). I hurried to add ... that this is only the material side of the process. The true product of the economic process is an immaterial flow, the use of life, whose relation with the entropic transformation of matter-energy is still mysterious (Georgescu-Roegen, 1976, p. 14).

The work of Georgescu Roegen is, in several aspects, innovatory regarding the rival neoclassic and Marxian schools. Though diametrically opposite, these have common aspects.

\footnotetext{
${ }^{4}$ On the question of sustainable development, the ideas of Georgescu-Roegen are extremely innovatory, beginning with the idea that, strictu sensu, there is no self sustainable economic development, when it is taken into account that the economic system is not like a perpetual motion mechanical system, but like an evolutive entropic process that marches inexorably towards extinction. In this sense, environmental preservation must not make absolute sustentainability as its objective, although it is impossible, but the maximization of the possibility of life on the planet.

${ }_{5}^{5}$ Before his conversion, Georgescu-Roegen was an exponent of the theoretical inquiry of the neoclassic mainstream, having presented insights that inspired several of the principal economic theorems subsequently developed by other eminent neoclassics like Paul Samuelson. For many people, only the set of his theoretical work in the neoclassic economy would have been sufficient to make it deserve the laurel of the Nobel Prize in economy.

(C) RGSA - v.4, n.1, jan./abr. 2010

www.gestaosocioambiental.net
} 
Both emphasize the urbane, capitalist and individualist market system and, in the beginning, disregard the environmental impacts of the industrial-urbane expansion. The first one because it is reducionist and abstract, for nature, second because it has the history of the theory of class struggle as its main focus, it is more concerned with the exploitation of man by man than with environmental degradation ${ }^{6}$.

Georgescu-Roegen and E.F. Schumacher are among the first to realize that the economic calculation is ethically mistakenly when it reduces several types of inputs from the productive process to a sum of costs without taking into account certain essential differences between the involved categories. According to Georgescu-Roegen, the productive activity can be seen as a process that requires the presence of three different types of factors that he designates as factors 'fund' 'flow' and 'stock'. The flow factors are the materials that enter in the process and, transformed by the action of the base factors, they go out incorporated into the product. Among the base factors there is a need to make a distinction between those which can be replaced, like work and capital, the first by vegetative growth of the population, and the second by replacement investments and those that necessarily appear in a finite quantity "not - reproducible", as is the case of land and the reserves of fuels fossils and other mineral raw materials. Meanwhile, in economic terms, no distinction is made between them; they all have a cost that is determined by their 'market prices'. So, the non-renewable stock factors, like coal and oil, are treated by the present generation like all other types and its prices determined by the respective 'costs of production', on one side, and by the demand of the present generation, on the other. The energy necessities of future generations are not taken into account ${ }^{7}$. As these factors are determined by the current supply and demand, the prices end up being underestimated by the present generation. In this case, from the point of view of a correct economic theory, the market fails in determining the price because it does not to take into account shortages, in its proper dimension ${ }^{8}$.

Other interesting insights of Georgescu-Roegen were inspired in the observation of socialeconomic scenarios naturally based on cooperative and supportive behaviors typical of certain local and superpopulous, agriculturally based, and underdeveloped ${ }^{9}$ economies. If the technique of usefulness and production functions were applied to these scenarios it must be prepared to take into account at least two great differences related to the usual neoclassic treatment. The first thing to consider is that the well-being of a typical individual doesn't only depend on his consumption possibility, but also others member of community consumption possibilities. Formally this can be represented by a utility function $U=f(y, x)$, in which $y$ represents consumption capacity of the individual (i) and $x$ the particular criteria concerning communitarian welfare. Under the

6 In fact, Marx had no time to be present at the environmental implications of the capitalist industrialization, which in his time was certainly a problem much less visible than the conditions of life of the nascent working class. The habit of neglecting the environmental questions of the Marxists who came then seems to result also from the belief of which to the end of the history of the class struggle all the problems of the humanity will be resolved.

${ }^{7}$ In case of the price of the oil, for example, only the cost of extraction is considered, on one side, and the demanded quantity, on the other. When, in a determined state of affairs, the demand falls, this causes an increase in the reservoirs of already extracted oil, setting up a tendency for price reduction, and vice-versa. If new, more accessible deposits are discovered then the cost of extraction will have a tendency to fall, being associated also to a tendency in reduction of price, and vice-versa. So, the price of oil, whose existent quantity in the planet is fixed, and as such will one day become exhausted, ends up being treated as an agricultural commodity, whose production can be maintained indefinitely in a continuous flow, although it depends on the existence of base factors and on undepletable flow factors.

${ }^{8}$ If the price of oil incorporated this "true" shortage certain comforts of modern life, such as cars, would be economically impracticable. The american way of life can be seen as a distortion resulting from this mistake.

${ }^{9}$ Such scenarios were relatively common in the time of his youth in Romania and other eastern European countries.

(C) RGSA - v.4, n.1, jan./abr. 2010

www.gestaosocioambiental.net 
conditions $f^{\prime}(y)>0$ and $f^{\prime}(x)>0$, this function implies that the utility of an individual do not dependent only of his own income but of the total income distribution among the members of the community. That is the case for small communities in which each member knows the situation of the others and is conscious of the interdependencies between them, in contrast to the utility function of the metropolitan man, for whom the variable $x$ is only relevant, according to the neoclassical assumption.

In such situation, the profit maximization criteria also does not make sense, once, due to the excess of population and relations to too many base factors, the objective of maximization of the community income ends up surpassing any individualistic objective of profit maximization.

Apparently, it was the consideration of special economic characteristics of these economic systems which inspired Georgescu-Roegen to propose the physical thermodynamic analogy as more appropriate for the economy than the mechanical analogy of Galileu and Newton. It is true that humanity, as a whole, is still far from facing the severe restrictions already observed in certain local overpopulated economies, for which the logical principals discussed above are applied. However, if it was properly considered that as a result of the inevitable positive entropia of the economic process this type scenario is what humanity will unavoidably reach, this would be the wisest perspective.

There is no doubt that, in harmony with the second law of thermodynamics; the economic activity of homo sapiens contributes to the increase of the positive entropia of the planet, a reason for which Georgescu-Roegen considered the Law of Entropia as "the most naturally economic of all natural laws." The resultant way of life of the "fordism" industrialization constitutes aggravating factors that, not only due to "cars are being more 'entropic' than the buggy", and the "donkey being less 'entropic' than the motorcycle", but principally because the process of mass production increased the use of machines, increasing the conversion rate of non-renewable natural resources into non recyclable residues.

The fascination provoked by "technological wonders", made possible by the discovery of the laws of mechanics and eletromagnetism, on a hand, and the progressive loss of human contact with "the wonders of nature", as a consequence of the industrial-urbane expansion, contributed to the affirmation of the mechanistic model in the economical theory and as a way of thinking that associates progress with economic growth measured by the expansion of GNP. From the biological point of view, such a change must be seen as more of a threat than human progress. This is another notable insight of Georgescu-Roegen which creates a new perspective for economic science, where a "biological essence" is revealed in economic activity, in general, and especially in technological development. This is the reason why, since the 1970's, this new perspective began to be designated as bioeconomy.

Georgescu-Roegen borrowed the terms exosomatic, to designate the instruments and artificial mechanisms that man invents, and endosomatic to designate the natural physical entities of living beings, from the biologist Alfred Lotka. A lion when it kills a prey uses only endosomatic organs like claws, jaws and teeth. Man, however, in order to kill, utilizes instruments like weapons created by himself. One distinctive characteristic of humans from other animal species is the fact that he is the only one who uses cerebral capacity to produce exosomatic organs. This is the basic reason for him having become the dominant species, among all other forms of life. But they are not exclusive to human beings. Some animal species also use them, like the birds that make nests and bees that build hives, for similar reasons that man builds beds or houses. What distinguishes humans is their capacity to produce and incessantly invent exosomatic instruments, not by genetic instinct, like birds and bees, but a rational activity. The 
human species like all living species is subject to an endosomatic evolutionary process, in accordance with the Darwin's law. The difference from the other species is that the human species also evolves in exosomatic ways.

In this sense, economic activity is an extension of biological activity. The produced entities are used and spread to support a new way of life. From this point of view, the economy is essentially a 'bioeconomy', since it involves the evolution of the existence of man, as a species, and not as an individual only interested in maximizing profits (Georgescu-Roegen, 2003, p. 187-88).

Providing an extension of human capacities, the development of exosomatic entities, as a process of "facilitating life", be it through the reduction of effort or the increase of comfort and pleasure provided to man, establishes a vicious dependency. Another consequence of this is the inequality in the distribution of benefits from this evolution among the class that plans, organizes, supervises and controls the production, which Galbraith (1977) called the technostructure, and the class "which simply participates in this production". In order to use the terms of GeorgescuRoegen, it is the conflict between "those that govern" and "those who are governed." The human species reveals other differentiating characteristics from other species, as a biological being stipulated by biophysical processes and socially molded by institutional standards.

The problem with exosomatic dependence is that it puts humanity on a collision course with inevitable limits established by a finite endowment of natural resources. Once, as Galbraith already demonstrated, that it is by mechanisms through which this dependence is intensified that members of the technostructure reaffirm their governing power, this class will take on the role of the villain in the environmental tragedy announced by Georgescu-Roegen.

\section{KANTIAN CATEGORICAL IMPERATIVE AND SUSTAINABLE DEVELOPMENT}

The kantian imperative can be formulated in the following way: act in such a way that the maximum of your actions can become universal law, or act in a way that the motive that caused you to act can become universal law.

I do not need far sided insight to know what I should do so that my desires are morally good. Inexperienced as to the course of worldly things, incapable of prevention in view of events that in themselves come to give, it is enough to ask myself: - Can you also desire that your maxim converts itself into universal law? (Kant, 2004, p.35).

According to this principle all individuals must fulfill their moral duty and provides the universal criteria, which actions should be conducted (Hamm, 2003).

Scanlon (1998, p.153), in an attempt to explain the categorical imperative and the kantian universal law affirms that:

An act is wrong if its action in the current circumstances is unauthorized by any set of principles for the general regulation of behavior that no one could reasonably reject as the base of a clarified and not compelled general agreement (Scanlon, 1998, p.153).

Trying to better explained the "categorical" imperative; Kant (2004) presents four examples: suicide, lying, concealing talents and worry of others. First he considers the case of individual thinking of commit suicide to get rid of extreme difficulties. It is possible to transform the suicide in universal law? Obviously not, he affirms, since death can never be the solution to problems. 
In a second example, he takes the case of a individual in financial difficulty trying borrow money that promises to settle the debt on a determined date. She knows that she is not going to be able to honor her promise, but, if she does not do that she will not get the money that she needs. From there can be argued: is it possible to establish the lie as the basis for a universal law? All men must lie to achieve his objectives?

Quickly I recognize that I can in truth want to lie, but that I cannot want a universal law of lying; according to such a law, it could not proportionally carry any promise, because it would be useless to affirm my will relative to my future actions to people that do not believe in my affirmation, or if they hastily do so, they would pay me with the same coin. Consequently my maximum, once rooted in universal law, would necessarily destroy itself (Kant, 2004, p.34).

The third example concerns to concealing talents. If a person has determined skills and does not make an effort to perfect them this cannot become universal law. So, according to Kant (2004), this behavior does not stimulate the person to perfect his potential and face challenges.

Last but not least, a final example illustrates the case of a person who sees a needy person and can help to alleviate his pains but does absolutely nothing. In this case can be asked: the lack solidarity could become universal law? The answer is no, since without solidarity human kind could not exist.

Mendonça (2003) summarizes in the following way the nucleus of universality and Kantian imperative:

\footnotetext{
The reasonable nucleus of this "test of universality of maximums" is the following: in many cases we can show that an option is morally wrong with an argument that begins with the question "and if everyone acted this way?" So we can show that it is wrong to step on the grass, withhold taxes and not honor promises previously made. The kantian test supplies us with, at best, a necessary condition for moral choices (Mendonça, 2003, p.21).
}

From these considerations arises an inquiry about what criterion should be followed to guide individual action in accordance with a universal law. Here Kant (2004) stresses the criterion of goodwill. For him good will is free, autonomous, and the actions are not determined or random and so could serve as a basis for a universal law of human behavior. Nevertheless, as expressed by Pascal (2005), temptations can divert men of good will path.

Based on Kantian concepts, it is possible to make a mix among the epistemological elements about the sustainable development with the Kantian philosophical requiring. Men know that sustainable development is a prerequisite to enlarge the chances of future generations enjoy the miracle of life on a planet wonderful. But why doesn't society worry about sustainable development and make it universal law, molding it to the kantian imperative, since it's hard to find better reasons of goodwill than environmental sustainability?

It starts to be noticed an involvement on engagement of certain social segments in defense of sustainability. Universities, NGOs, Private and Public Organizations, some Governments and, recently, even the media. This movement that has been advancing over the last few years has been arousing the conscience of more and more individuals.

In effect, as exposed here, there is a strong linkage joining kantian philosophical precepts and the bioeconomy of Georgescu-Roegen. The next passage, taken from one of his last texts, makes that quite clear: "A new ethics emerges from bioeconomy and its order is: "love your species as yourself". (Georgescu-Roegen, 2003, p. 190). 
Without having, except by mistake, made reference to Kant in his writings, the proposal of a new economic order, by Georgescu-Roegen, which became known as the "minimum bioeconomy program" admirably fits the spirit of the Kantian imperative. The program is composed by a set of eight recommendations ${ }^{10}$. There is nothing in them that has not already been said by pacifists, critics of the consumer society, ecologists or existentialist philosophers. The difference is that it is not based on anything that could be confused as religion, ideology or romanticism, but rather an economic perspective that, without contradicting the most accepted scientific canons, establishes a common view point between different disciplines like ethics, biology and economy.

Nevertheless, Georgescu-Roegen was aware of the elevated degree of "utopianism" of his proposal. He was realistic and skeptical in terms of the acceptance of any program that appealed to a drastic reduction of material comfort:

[...] Perhaps, the destiny of the humanity is to have a short life but, burning, exciting and extravagant, instead of a long, however monotonous and contemplative existence. We let other species - the amoebae, for example, - that has no spiritual ambitions inherit a land still abundantly sunny. (Georgescu-Roegen, 1976, p. 35).

He also anticipated the reaction of the great powers to the proposal of global environmental control, as demonstrated by the position of George Bush's administration, regarding the Kyoto protocol. The incursion of the USA into the Middle East also seems to indicate well the answer to the inquiry: "What can a great power decide, armed with nuclear warheads, if a time arrives when there is not sufficient energy to maintain his exosomatic system operating?" (Georgescu-Roegen, 2003, p. 190).

\section{CONCLUSIONS}

The general objective of this article was to bring some reflections on the question of sustainable development, involving economy, biology and philosophy, in general, and particularly to present the ideas of Nichollas Georgescu-Roegen that establish notable contacts between these three disciplines. Specifically it tried to show some ideas and proposals of a thinker whose work is being gradually rescued, after long and certainly not occasional ostracism, establishing a connection with analytical presuppositions of moral kantian philosophy.

The search for sustainable development, besides demanding cultural, political, and economic order changes, demands changes in the attitudes of mankind, who needs to develop a more complex and more multidisciplinary vision on this development aiming to provide the conditions so that society can reach it.

The basis of kantian ethics, in spite of having being formulated almost two centuries ago, is still current. When the good will of men exists the search for sustainable development may be considered a universal law. Nevertheless, as Kant (2003) warned, very often man, by his attitudes, inclinations and preferences does not do good will. In a way, at present, this is what still happens with sustainable development. It is a concept that is still not a priority for society by reasons of human inclinations for other things like maximum profit and "exosomatic wonders" of a post-modern society.

\footnotetext{
${ }^{10}$ More precisely, the program contains eight items, among which are favorable recommendations to help underdeveloped countries and agrarianism, and oppose the production of armaments, conspicuous consumption, marketing and planned technological obsolescence.

(C) RGSA - v.4, n.1, jan./abr. 2010

www.gestaosocioambiental.net
} 


\section{REFERENCES}

Anton, W. R. Q., Deltas, G., Khanna M. (2004). Incentives for environmental self regulation and implications for environmental performance. Journal of Environmental Economics and Management, v.48, p.632-654.

Aristotle. (2004). Nicomachean Ethics. Oxford: UK.

Aristotle . (2004). Politics. Harvard University, 2004.

Banerjee, S. B. (2003). Who Sustains Whose Development? Sustainable Development and the Reinvention of Nature. Organization Studies v. 24, p.143-180.

Bansal, P. (2005). Evolving sustainably: A longitudinal study of corporate sustainable development. Strategic Management Journal, v.26, p. 197-218.

Barin-Cruz, L; Pedrozo, E.; Estivalete, V. (2006). Towards Sustainable Development Strategies: A complex view following the contribution of Edgar Morin. Management Decision, v.44, n.1, p.871-891.

Buysse, K.; Verbeke, A . (2003). Proactive Environmental Strategies: A stakeholder management perspective. Strategic Management Journal,.v.24, n.5, p. 453-470.

Carson, R . (1962). Silent Spring. Houghton Mifflin.

Cherques, H. R.T. (1997). Max Weber e a ética nas organizações: cinco hipóteses sobre a cultura e a moral a partir de conceitos de Max Weber. Revista de Administração Pública. Rio de Janeiro, v. 31, n. 2, p.5-20

Galbraith, J. K. (1967). The New Industrial State. Princeton Universty Press.

Georgescu-Roegen, N. (1971).The Entropy Law and the Economic Process, Cambridge, MA: Harvard University Press.

Georgescu-Roegen, N. (1976). Energy and Economic Myths. New York: Pergamon Press, 1976.

Georgescu-Roegen, N. (2003).Bioeconomia e etica. In BORINGHERI, B. (ed.) Bioeconomia. Torino: Corso Vittorio Emanuele II, Itália.

Gladwin, T.; Kennelly, J.; Krause, T. (1995). Shifting Paradigms for sustainable development: implications for management theory and research. Academy of Management Review, v.20, n.4,p. 874-907.

Greaker, M. (2003). Strategic environmental policy; eco-dumping or a green strategy? Journal of Environmental Economics and Management. v.45, p.692-707. 
Hamm, C. (2003). Princípios, motivos e móbeis da vontade na filosofia prática kantiana. In: Napoli, R.; Rossato, N.; Fabri, M. (Orgs.). Ética e justiça. Santa Maria: Palloti.

Loreto, E. (2003). Origem da vida e evolução. In: Mota, R. et al. Método científico e fronteiras do conhecimento. Santa Maria: UFSM.

Kant, I. (2003). The Critique of Practical Reason. Oxford: UK.

Kant, I. (2004). The Metaphysical Elements of Ethics. Harvard University.

Mendonça, W. (2003).Como deliberar sobre questões morais In: Napoli, R; Rossato, N. Fabri, M. (Orgs.). Ética e justiça. Santa Maria: Palloti.

Morin, E. (2005). La Me'thode 6: É thique, Seuil, Paris.

Napoli, R. (2000). Ética e compreensão do outro. A ética de Wilhelm Dilthey sob a perspectiva do encontro interétnico. Porto Alegre: EDIPUCRS.

Pascal, G. (2006). Compreender Kant. Petrópolis, RJ: Vozes.

Plato. (2004). Republic. Oxford: UK.

Rawls, J. (2002). A Theory of Justice. Cambridge: Harvard University Press.

Russo, M. (2003). The emergence of sustainable industries: Building on natural Capital. Strategic Management Journal. v.24, n.4, p.317-331.

Sartre, J. P. (1996).Existentialisme est un humanisme. Paris: Folio France.

Scanlon, T. M . (1998). What we one owe to each other ? Cambridge, Mas.: Harvard University Press.

Sharma, S.; Henriques, I. (2005). Stakeholder Influences on Sustainability Practices in the Canadian Forest Products Industry. Strategic Management Journal, v.26, n.2, p.159-180.

Schumacher. E. F. (2006). Small is beautiful. Wilmington: ISI Books.

Spangenberg, Joachim H. (2004). Reconciling sustainability and growth: criteria, indicators, policies. Sustainable Development. v.12, p.74-86.

Spinelli, M. (1998) Filósofos pré-socráticos: primeiros mestres da filosofia e da ciência grega. Porto Alegre: EDIPUCRS.

Spinelli, M. (2002). Helenização e Recriação de Sentidos: a filosofia na Época da Expansão do Cristianismo - Séculos II, III e IV. Porto Alegre: EDIPUCRS.

(C) RGSA - v.4, n.1, jan./abr. 2010

www.gestaosocioambiental.net 
Sócrates. (2002). Vida e pensamento. São Paulo: Martin Claret.

Vázquez. A. S. (2006). Ética. Fondo de Cultura Económica: México.

Weber, M. (2004). The Protestant Ethic and the Spirit of Capitalism. Oxford: UK.

World Commission on Environment and Development. (1987). Our Common Future. New York: Oxford University Press. 